\title{
Peningkatan Ekonomi Masyarakat Melalui Keterampilan Membuat Nugget Berbahan Dasar Ikan Bandeng Sebagai Bahan Pangan Lokal
}

\author{
Anharudin $^{1 *}$, Donny Fernando ${ }^{2}$, Saefudin $^{3}$, Diki Susandi $^{4}$, Saleh Dwiyatno ${ }^{5}$ \\ $1,2,3,4,5$ Fakultas Teknologi Informasi, Universitas Serang Raya \\ Jln. Raya Serang Cilegon KM. 5 Taman Drangong, Serang - Banten \\ *e-mail : anhar.dean@gmail.com
}

\begin{abstract}
ABSTRAK
Meningkatkan taraf hidup menjadi salah satu faktor yang sangat penting dalam kelangsungan hidup bermasyarakat. Hal ini harus terus di dukung seiring perkembangan dan daya saing pada era globalisasi saat ini. Berdasarkan hasil pemetaan/assessment diketahui bahwa kelurahan Sawah Luhur memiliki potensi alam yang melimpah, namun belum didukung oleh sumber daya manusia yang terampil terutama dalam hal pengolahan makanan. Sehingga kondisi kehidupan masyarakat, terutama pada aspek ekonomi belumlah memadai, hal ini disebabkan oleh beberapa faktor seperti kondisi kualitas SDM yang masih rendah dan infrastruktur desa yang juga belum memadai. Tujuan utama dalam kegiatan pengabdian ini adalah memberikan Pelatihan dan Penyuluhan kepada masyarakat Kelurahan Sawah Luhur. Yang dilakukan baik secara teori maupun praktik dalam upaya peningkatan ekonomi masyarakat melalui keterampilan membuat nugget berbahan dasar ikan bandeng sebagai bahan pangan lokal. Dengan adanya kegiatan semacam ini, diharapkan dapat meningkatkan perekonomian dan menstimulasi terciptanya inovasi dan kreativitas untuk menciptakan produk lokal unggulan.
\end{abstract}

Kata Kunci : Ekonomi masyarakat, Keterampilan, Produk lokal. 


\title{
Improvement of Community Economy through the Skill of Making Milkfish Based Nuggets as Local Food Materials
}

\begin{abstract}
Improving the standard of living, is one of the most important factors in community survival. This must continue to be supported along with developments and competitiveness in the current era of globalization. Based on the results of mapping / assessment, it is known that Sawah Luhur Village has abundant natural potential, but it has not been supported by skilled human resources especially in food processing. So that the living conditions of the community, especially in the economic aspects are not yet adequate, this is caused by several factors such as the still poor quality of human resources and inadequate village infrastructure. The main objective in this service activity is to provide training and counseling to the community of Sawah Luhur village. What is done both in theory and practice in an effort to improve the community's economy through the skill of making milkfish-based fish nuggets as local food ingredients. With this kind of activity, it is expected to improve the economy and stimulate the creation of innovation and creativity to create superior local products.
\end{abstract}

Keywords: Community Economics, Skills, Local Products.

\section{PENDAHULUAN}

Kecamatan Kasemen adalah satu dari enam kecamatan yang berada di kota Serang. Kecamatan Kasemen merupakan wilayah pembangunan bagian utara dari kota Serang. Wilayah pembangunan bagian utara ini diarahkan dengan fungsi utama pariwisata cagar budaya dan cagar alam, pelabuhan, perdagangan dan jasa, perumahan dan berbagai fasilitas umum. Berdasarkan data publikasi resmi Badan Pusat Statistik kota Serang, dalam Kecamatan Kasemen Dalam Angka 2018, secara administrasi wilayah kecamatan Kasemen terbagi menjadi 166 Kampung/Lingkungan, 73 Rukun Warga (RW), 260 Rukun Tetangga (RT). Dengan jumlah penduduk 94.992 jiwa, yang terdiri dari 49.817 jiwa laki-laki, dan 46.175 jiwa perempuan.

Kecamatan Kasemen memiliki luas wilayah $56,36 \mathrm{Km}^{2}$, dengan batas-batas Kecamatan sebagai berikiut :

$\begin{array}{ll}\text { Utara } & \text { : Laut Jawa } \\ \text { Selatan } & \text { : Kecamatan Serang } \\ \text { Barat } & \text { : Kecamatan Kramatwatu } \\ \text { Timur } & \text { : Kecamatan Pontang }\end{array}$

Luas wilayah tersebut terbagi dalam 10 kelurahan, yakni kelurahan Kasemen, kelurahan Warung Jaud, kelurahan Mesjid Priyayi, kelurahan Bendung, kelurahan Terumbu, kelurahan Sawah Luhur, kelurahan Kilasah, kelurahan Margaluyu, kelurahan Kasunyatan, dan kelurahan Banten. kelurahan Sawah Luhur merupakan kelurahan dengan luas wilayah paling luas, yakni seluas $11,87 \mathrm{~km}^{2}$, atau 21,06 persen dari total luas Kecamatan Kasemen. 
Dengan luas wilayah demikian, daerah ini masih didominasi oleh pertanian lahan basah. Karena letak geografis daerah ini yang berada di pesisir pantai. Sejalan dengan hal tersebut, mayoritas penduduk wilayah ini bermata pencaharian sebagai petani dan peternak ikan.

Kampung Kebasiran yang menjadi tempat kegiatan Pengabdian Masyarakat merupakan salah satu kampung yang berada di Kelurahan Sawah Luhur. Tak cukup berbeda dengan kampung lain di Kelurahan Sawah Luhur, mayoritas penduduk di kampung ini bermata pencaharian sebagai petani dan peternak ikan. Salah satu komoditas unggulan masyarakat wilayah ini adalah ikan bandeng. Ikan bandeng yang dihasilkan dari wilayah ini, rata-rata dapat memenuhi kebutuhan supplai ikan di pasaran. Sehingga wilayah ini memiliki khas dengan daerah penghasil ikan bandeng.

Sebagai daerah penghasil ikan bandeng, wilayah ini tentu memiliki segudang potensi pengembangan ekonomi kreatif yang cukup bagus. Hal ini terlihat dari kurang beragamnya pengolahan ikan bandeng untuk dimanfaatkan sebagai kuliner khas. Padahal, wilayah ini cukup terkenal dengan kuliner pecak bandeng, ditambah letak wilayah ini yang cukup dekat dengan objek wisata kenamaan yakni Banten Lama. Jarak yang cukup dekat dengan objek wisata, seharusnya membuat wilayah ini terus berkembang, terutama dalam segi kuliner yang dapat mendorong perekonomian masyarakat. Hal inilah yang melatar belakangi perlunya pengabdian di wilayah ini. Untuk mengoptimalkan pengembangan ekonomi, terutama ekonomi kreatif.

Kegiatan Pengabdian Masyarakat dipandang sangat perlu untuk membantu mendorong masyarakat dalam berpikir kreatif dalam segi ekonomi. Kegiatan Pengabdian Masyarakat ini dilaksanakan di kampung Kebasiran. Dari satu kampung ini, tim bersama mahasiswa berharap dapat melakukan pengabdian untuk menambah wawasan masyarakat dalam kegiatan ekonomi, salah satunya inovasi pengolahan komoditas unggulan, yakni Ikan Bandeng. Perencanaan program yang matang dari segi kesiapan pelaksanaan dan perangkat lainnya juga akan berdampak positif terhadap apa yang menjadi tujuan dan maksud dari program tersebut.

Menurut Ife (2008), ada beberapa hal yang harus diperhatikan pada proses community development untuk mendorong partisipasi masyarakat yaitu masyarakat harus mengetahui serta menyadari bahwa masalah tersebut penting dan tindakan setiap orang akan membawa perubahan sehingga apapun bentuk partisipasinya harus diakui, dihargai serta didukung.

Berdasarkan pernyataan di atas, maka tahapan penting dalam sebuah program kemasyarakatan harus melalui proses yang dinamakan community development terlebih dahulu, yang didalam proses tersebut terdapat proses Assessment. Proses ini yang akan mengindentifikasi serta mengumpulkan masalah-masalah atau polemik yang ada dimasyarakat tersebut, untuk kemudian dijadikan bahan kajian. Sehingga kemudian dapat dicarikan solusi dan program community development yang akan dilakukan akan tepat sasaran dan berdasarkan masalah dan kebutuhan yang diharapkan oleh masyarakat setempat. 


\section{METODE}

Metode pelaksanaan pengabdian kepada masyarakat yang dilakukan melalui pelatihan ini dibagi menjadi 2 kegiatan yang akan dijelaskan sebagai berikut:

\section{Tahapan Assessment}

Pada tahap awal pelaksanaan kegiatan ini adalah melakukan assessment yang dengan melakukan pengkajian maupun penilaian terhadap keadaan wilayah atau desa tempat melakukan pengabdian masyarakat tersebut. Masyarakat dilibatkan langsung untuk turut ikut memberikan informasi terkait keadaan dan kondisi kehidupan mereka. Salah satu metode assessment yang digunakan untuk melakukan kegiatan tersebut adalah PRA (Participatory Rural Apprasial). PRA memiliki beberapa teknik yang bisa kita ambil, karena memiliki karakteristik selalu terbuka untuk menerima cara-cara dan metode-metode baru yang dianggap cocok. Sehingga mudah diterapkan dalam rangka menggali potensi, bisa dilihat dari keseharian kehidupan masyarakat tersebut, sehingga kita dapat menentukan metode apa yang tepat dalam penuntasan permasalahan-permasalahan yang terjadi selama ini di masyarakat setempat. Selanjutnya kita dapat melibatkan masyarakat setempat untuk kemudian melakukan peningkatan kesejahteraan dan taraf hidup masyarakat setempat.

Pelaksanaan kegiatan pengabdian ini dilaksanakan dalam upaya peningkatan ekonomi masyarakat melalui ekonomi kreatif. Yakni dengan menumbuhkan inovasiinovasi dalam pembuatan makanan berbahan dasar ikan bandeng sebagai komoditas unggulan wilayah pelaksanaan kegiatan pengabdian. Dalam pelaksanaannya, kegiatan pengabdian ini dilaksanakan dengan memberikan pelatihan langsung yang secara langsung dipraktikkan kepada masyarakat. Pelaksanaan kegiatan ini dilaksanakan di bulan Juni 2019. Dengan beberapa tahap yang di lalui, mulai dari pendekatan, observasi dan terjun langsung kepada masyarakat. Sehingga dapat digali dan melihat langsung problem yang terjadi di lingkungan masyarakat tersebut.

\section{Tahapan Pelatihan}

Kegiatan ini dilakukan dengan cara memberikan pelatihan kepada masyarakat desa setempat, dengan dilengkapi alat bantu seperti alat-alat masak, kemudian bahan dasar ikan bandeng yang masih segar, lalu bumbu-bumbu masak dan lain sebagainya. Pelatihan dan penyuluhan ini dilaksanakan oleh lima orang narasumber, dibantu oleh mahasiswa. Kegiatan ini dilakukan dengan memberikan penyuluhan berupa edukasi mengenai bagaimana cara berwirausaha yang baik, serta memberikan beberapa eksperimen dan contoh bagaimana memulai untuk berani berwirausaha serta bagaimana strategi yang diambil sehingga produk dapat dipasarkan dan memiliki nilai jual yang tinggi. Selain itu juga kami sebagai narasumber memberikan pengetahuan tentang bagaimana membuat inovasi produk. Agar tidak itu melulu dan terkesan monoton, dari ikan bandeng yang selama ini diolah menjadi makanan yang belum banyak variasinya. Dengan kegiatan pengabdian ini, tim memberikan pelatihan bagaimana mengolah ikan bandeng menjadi nugget. Sehingga bahan dasar makanan ikan bandeng ini dapat bernilai ekonomi tinggi. Dan dapat dipasarkan serta dikenal sebagai makanan khas masyarakat setempat, selain makanan hasil olahan yang lainnya. 


\section{Published December 2019}

EKONOMIKAWAN : Jurnal IImu Ekonomi dan Studi Pembangunan

ISSN : 1693-7600 (Print), ISSN : 2598-0157 (Online), http://jurnal.umsu.ac.id/indexphp/ekawan

Dalam kegiatan ini dilakukan juga sesi tanya jawab dan interaksi langsung dengan peserta yang hadir untuk merespon keluhan dan masalah apa yang menjadi ganjalan masyarakat selama ini, terkait dengan permasalahan berwirausaha. Karena sampai saat ini kehidupan rata-rata masyarakat setempat masih rendah dalam segi penghasilan per bulan nya. Sehingga kesejahteraan hidup mereka masih di bawah rata-rata dan dibawah garis kemiskinan.

\section{HASIL DAN PEMBAHASAN}

Kegiatan pengabdian yang dilakukan di kampung Kebasiran, kelurahan Sawah Luhur kecamatan Kasemen kota Serang Banten telah dilaksanakan dengan lancar dan dengan hasil yang cukup baik dan memuaskan. Dengan dibantu oleh stakeholder seperti perangkat desa dan kecamatan setempat. Menjadikan kegiatan ini menjadi sangat bermanfaat dan menjadi bernilai bagi masyarakat setempat. Berdasarkan uraian pada bab sebelumnya mengenai metode pelaksanaan kegiatan yang dilakukan dengan dua cara, maka kami memperoleh hasil sebagai berikut:

\section{Tahapan Assesment}

Tahapan assessment merupakan langkah awal dalam metode yang dilakukan terkait kegiatan ini. Hasilnya dengan melakukan pemetaan yang telah dilakukan di desa Kebasiran kelurahan Sawah Luruh kecamatan Kasemen kota Serang Banten ini adalah didapatkan dari banyak aspek permasalahan yang ada. Mulai dari sangat sulitnya kebutuhan akan air bersih, untuk mandi, cuci dan konsumsi air minum sehari-hari. Hal ini dikarenakan lokasi atau tempat ini sangat berdekatan dengan laut Jawa. Sehingga air di lokasi ini bersifat payau. Air ini ketika digunakan untuk mandi sangat lengket. Apalagi untuk konsumsi air minum terasa sedikit hambar dan sedikit ada rasa asin. Kondisi ini juga berpengaruh terhadap kegiatan keagamaan, seperti penggunaan air untuk ibadah sholat. Karena mayoritas penduduk memeluk agama Islam. Di kelurahan ini kegiatan agama sangat rutin diadakan seperti pengajian mingguan, sholat fardhu berjama'ah dan perayaan hari besar Islam. Hal ini sangat berpengaruh juga terhadap tempat pelaksanaan kegiatan tersebut. Karena tempat ibadah seperti masjid menjadi sentra dari kegiatan tersebut. Yang menjadi masalah adalah tentang keberadaan masjid yang sangat memperihatinkan. Kondisi masjid atau mushola yang ada dilokasi kondisinya memang perlu diperbaiki. Sehingga jama'ah bisa nyaman melakukan ibadah di sana.

Kemudian permasalahan lainnya yaitu mengenai kesadaran akan pendidikan. Pola pikir masyarakat setempat yang masih beranggapan bahwa pendidikan bukan menjadi kebutuhan dan keharusan, menjadikan kondisi yang ada adalah demikian, yaitu masyarakatnya masih berpendidikan rendah. Padahal di lokasi ini sudah ada sarana pendidikan mulai dari Pendidikan Usia Dini sampai dengan Sekolah Menengah Pertama, bahkan ada Sekolah Menengah Atas yang sudah berdiri disana. Namun kesadaran untuk menyekolahkan anak-anak mereka masih kurang. Sehingga sarana pendidikan yang sudah ada tidak dimanfaatkan dengan maksimal oleh masyarakat setempat. Beberapa gedung dan sarana pendidikan di lokasi juga ada yang membutuhkan penanganan serius, karena gedung yang kurang perawatan, sehingga banyak yang rusak dan tidak layak untuk digunakan sebagai kegiatan belajar mengajar. 
Keadaaan potensi alam yang sangat melimpah menjadikan lokasi ini butuh penanganan yang lebih komprehensif dari kami sebagai tim yang sedang melakukan kegiatan pengabdian. Karena kelurahan Sawah Luhur ini sangat berpotensi untuk dikembangkannya sektor perikanan. Karena memang lokasinya yang strategis dekat dengan laut. Seharusnya banyak dibuatkan tambak atau keramba disana. Sebagai besar mata pencaharian masyarakat memang sebagai nelayan dan petani. Namun karena keterbatasan biaya dan sebagainya. Akhirnya hasil yang diperoleh belum maksimal. Dan belum cukup untuk memenuhi kebutuhan masyarakat. Masalah yang ada selama ini adalah terkait pengelolaan dan inovasi serta strategi pemasaran yang kurang maksimal untuk pengolahan bahan makanan terutama berbahan dasar ikan bandeng yang menjadi komoditas utama di kelurahan Sawah Luhur. Hal ini lah yang menyebabkan perekonomian masyarakat belum seutuhnya terangkat atau sejahtera.

Sementara untuk air bersih meskipun sudah masuk PDAM namun pasokan air bersih yang di alirkan kepada masyarakat belum cukup untuk memenuhi kebetuhan sehari-hari. dan dirasa masih kurang. Dalam sektor kesehatan masyarakat di sana mengalami banyak kendala. Memang sudah ada beberapa pusat kesehatan seperti puskesmas. Namun masyarakat enggan mendatangi puskesmas karena lokasi atau jarak yang jauh, padahal pihak terkait juga sekali dalam satu minggu melakukan kunjungan dengan membuka posyandu. Namun karena kesadaran dan pemahaman mengenai pentingnya hidup sehat masyarakat yang masih kurang, maka kegiatan posyandu juga tidak maksimal. Pola hidup masyarakat setempat juga masih jauh dari kata sehat, hal ini dilihat dari ketersediaan tempat MCK yang masih belum mereka sediakan di setiap rumah tangga. Sehingga ini yang menjadikan kehidupan masyarakat setempat dapat dikatakan jauh dari kata bersih dan sehat.

Pada bidang pertanian masyarakat setempat juga banyak mengalami kendala terkait masalah air yang harus dialirkan ke sawah, lalu kemudian ketersediaan pupuk karena terbatasnya dana untuk membeli. Kondisi selanjutnya adalah terkait ekonomi, warga masyarakat di kelurahan Sawah Luhur belum memiliki keterampilan yang memadai dalam hal membuat makanan yang di olah dengan bahan baku yang sebetulnya sangat melimpah ruah dari lokasi setempat. Di kelurahan Sawah Luhur sudah ada kelompok simpan pinjam baik dari hasil dari koperasi maupun swadaya yang dapat berfungsi sebagai lembaga keuangan yang dikelola di masyarakat.

Kemudian fasilitas sarana dan prasarana untuk sampai ke lokasi seperti kantor Kelurahan dan pemukiman warga sudah ada, hanya permasalahanya kondisi akses jalan yang kurang baik, Sebagian besar jalan sudah rusak, berlubang, belum diaspal dan tidak memiliki parit (saluran air) sehingga ketika musim hujan datang akan terjadi genangan air dan kotor oleh tanah. Berikutnya adalah kondisi sosial kemasyarakatan, tokoh masyarakat atau sesepuh dalam hal ini masih sangat berpengaruh dan memegang peranan penting dalam kehidupan bermasyarakat. Selain itu, nilai-nilai kebersamaan yang dianut oleh warga antara lain saling membantu sesama, saling menolong, peduli, dan saling percaya, demikian juga dengan budaya gotong royong atau kerjasama. Namun kondisi ini lambat laun akan terus berubah dan tergerus zaman terutama pada generasi mudanya. Banyaknya pengaruh perkembangan zaman digital seperti sekarang ini, akan menjadikan terkikisnya kebiasaan yang baik dimasyarakat yang sudah tertanam selama ini menjajdi hilang. 


\section{Published December 2019}

EKONOMIKAWAN : Jumal IImu Ekonomi dan Studi Pembangunan

ISSN : $1693-7600$ (Print), ISSN : 2598-0157 (Online), http://jurnal.umsu.ac.id/indexphplekawan

Belum lagi permasalahan tingginya angka pengangguran yang disebabkan oleh lapangan kerja yang terbatas dan kurang sesuainya keterampilan dengan lapangan pekerjaan serta pendidikan yang sangat rendah, menjadikan kondisi ini sangat memprihatinkan. Kondisi Kelembagaan, hasil dari observasi dan identifikasi di lapangan terlihat bahwa kondisi pemerintahan di kelurahan tersebut, baik dilihat dari segi sumber daya manusia maupun sarana prasarana termasuk bangunannya belum memadai, kondisi nya perlu adanya peningkatan kualitas terhadap sumber daya manusia yang ada, demikian juga kondisi bangunan banyak diperlukan renovasi dibeberapa bagian gedung atau bangunannya sehingga dengan begitu bisa meningkatkan kualitas pelayanan kepada masyarakat setempat.

\section{Tahap Pelatihan}

Pada tahap pelatihan ini, masyarakat menjadi semakin lebih mengetahui dan memahami tentang masalah-masalah yang berkaitan erat tentang bagaimana membuat bahan dasar komoditas lokal dalam hal ini berbahan dasar Ikan Bandeng menjadi produk yang berinilai ekonomi tinggi. Dalam pelaksanaan pelatihan dan penyuluhan ini juga masyarakat warga kelurahan Sawah Luhur dalam hal ini kampung Kebasiran sebagai lokasi kegiatan pengabdian, sangat antusias dan merespon dengan baik diselengarakannya kegiatan pelatihan ini. Hal tersebut dapat dibuktikan dengan banyaknya peserta yang hadir dan pada saat kegiatan berlangsung, masyarakat senang dan banyak melontarkan pertanyaan yang di tanyakan kepada kami sebagai narasumber pada kegiatan ini, kebanyakan dari peserta, mereka menanyakan terkait dengan konten dari materi yang kami berikan. Masyarakat juga mengharapkan kepada tim narasumber supaya kegiatan seperti ini terus digalakkan dan berkesinambungan ke depannya. Sebab di kelurahan Sawah Luhur ini masih banyak potensi, baik sumber daya alam maupun sumber daya manusianya yang belum terkeksplorasi secara lebih mendalam. Berikut beberapa dokumentasi pada saat kegiatan berlangsung :

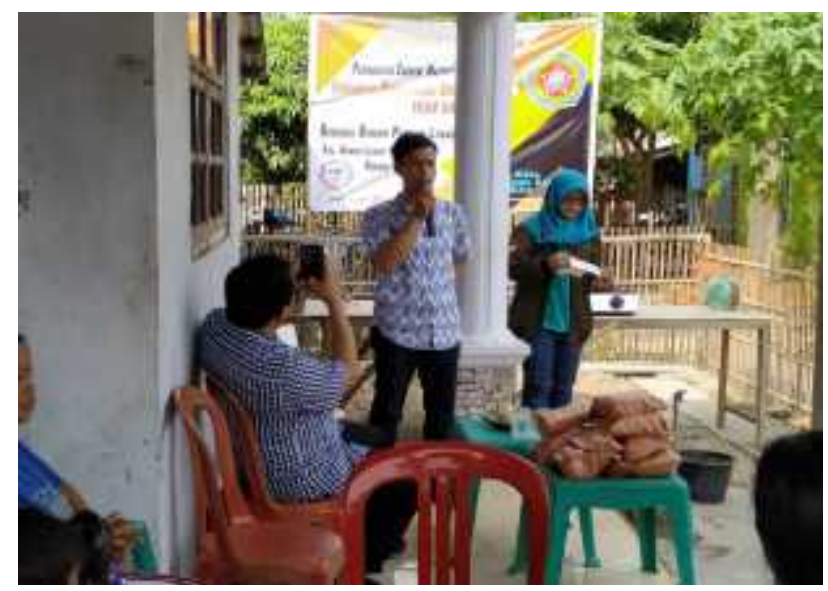

Gambar 1. Pemaparan Sosialiasi Produk Inovasi 


\section{Published December 2019}

EKONOMIKAWAN : Jurnal IImu Ekonomi dan Studi Pembangunan

ISSN : $1693-7600$ (Print), ISSN : 2598-0157 (Online), http://jurnal.umsu-ac.id/indexphplekawan

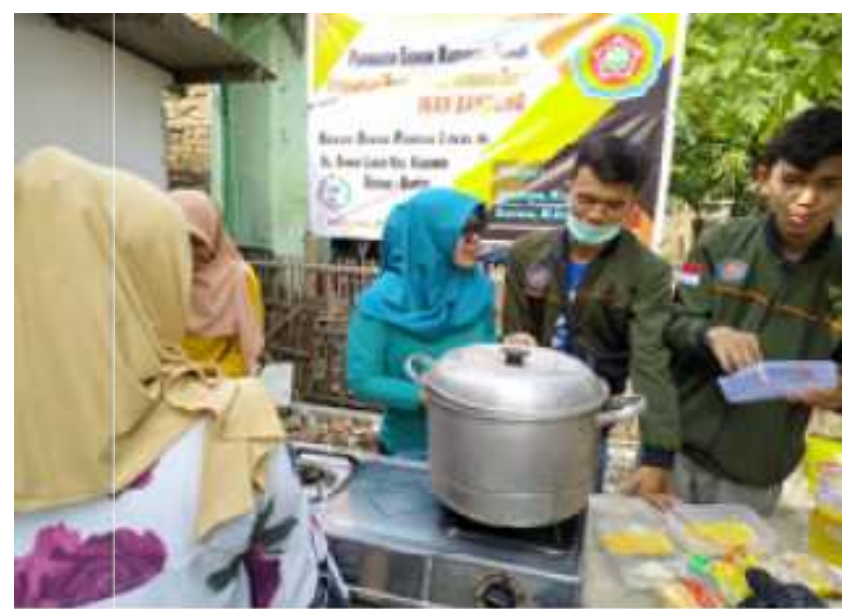

Gambar 2. Pelatihan Membuat Nugget dari Ikan Bandeng

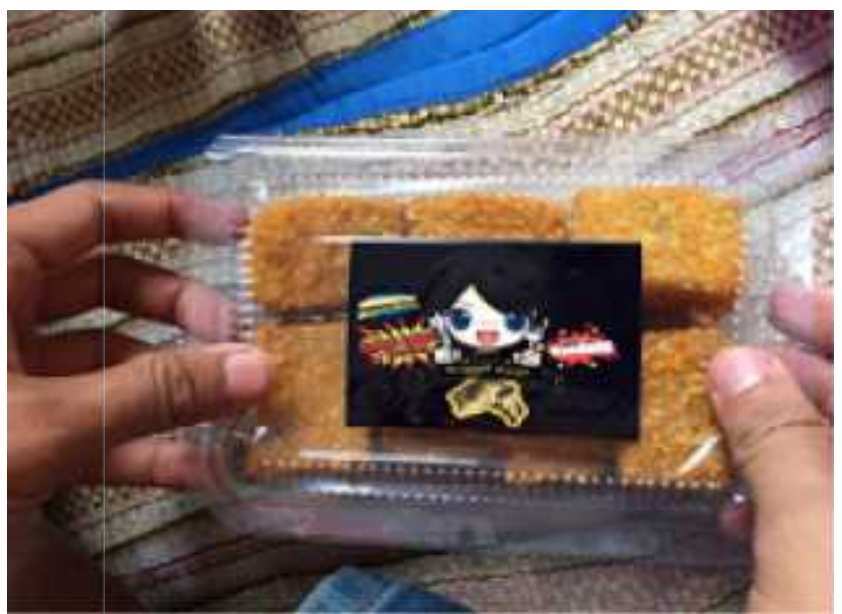

Gambar 3. Produk Nugget dari Ikan Bandeng

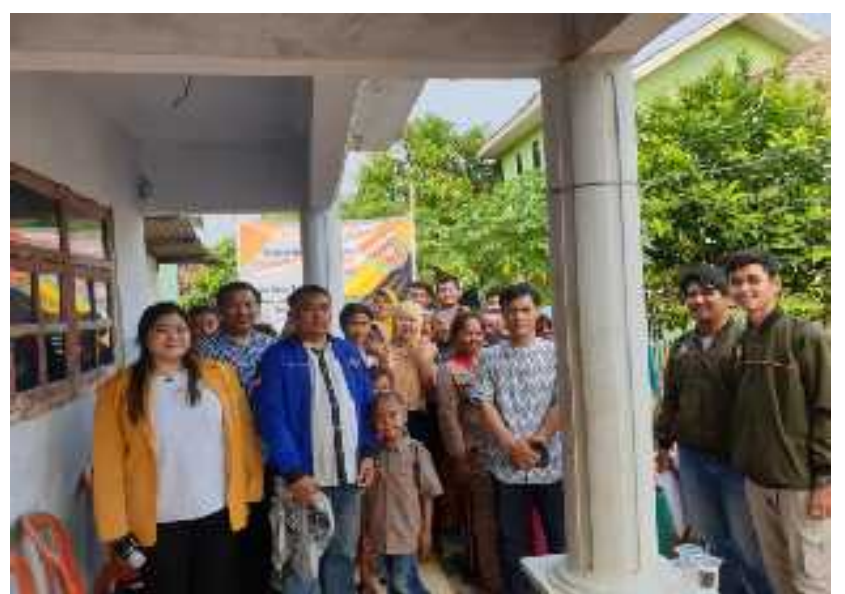

Gambar 4. Foto Bersama Tim dan Peserta Pelatihan 
Published December 2019

EKONOMIKAWAN : Jurnal IImu Ekonomi dan Studi Pembangunan

ISSN : 1693-7600 (Print), ISSN : 2598-0157 (Online), http://jurnal.umsu.ac.id/indexphp/ekawan

\section{Rencana Keberlanjutan Program}

Berdasarkan dari hasil kegiatan pengabdian yang telah dilaksanakan di kampung Kebasiran kelurahan Sawah Luhur kecamatan Kasemen kota Serang Banten, terutama kegiatan pelatihan mengenai keterampilan pengolahan bahan dasar ikan bandeng menjadi produk inovasi berupa nugget, sepertinya sangat perlu diadakan kegiatan yang bertujuan untuk meningkatkan kreatifitas berupa membuat kemasan hasil/produk yang lebih menjual dari kemasan yg sudah dibuat sebelumnya, dengan melibatkan lagi mahasiswa KKM yang berlatar belakang ilmu komputer untuk mendesain kemasan produk. Selain itu memberikan wawasan tentang bagaimana agar produk ini diakui oleh dinas-dinas terkait. Agar dapat diberikan label ijin, label kadaluarsa, dan lain sebagainya. Sehingga nantinya produk yang dipasarkan sudah memiliki legalitas minimal dari Pemerintah Kota. Kegiatan pelatihan ini juga dapat dilakukan dengan menambahkan kegiatan yang bertujuan untuk memaksimalkan sumber daya kelompok usaha yang sudah ada sebelumnya atau bisa juga dapat dibentuk kelompok yang baru dengan memberdayakan masyarakat di kelurahan Sawah Luhur, terutama kaum ibu-ibu. Untuk selanjutnya tim melakukan pendampingan dan pemantauan terkait perkembangan kelompok usaha yang telah dibentuk sebelumnya.

\section{KESIMPULAN}

Berdasarkan berbagai kegiatan yang telah dilaksanakan, secara keseluruhan dapat disimpulkan bahwa sebagian besar program berjalan dengan baik. Mulai dari tahap assesment hingga pelaksanaan tahap pelatihan. Hasilnya, ibu-ibu peserta pelatihan dapat mengikuti kegiatan dengan sangat antusias dan dapat membuat nugget sebagai produk hasil inovasi kegiatan ini dengan baik, sehingga diharapkan dapat menularkan kepada ibuibu lain yang berhalangan hadir pada pelaksanaan kegiatan pengabdian ini.

\section{DAFTAR PUSTAKA}

Alam, Heldy Vanni. dan Salma, Bowtha. 2017. Optimalisasi Pemberdayaan Usaha Mikro Dalam Upaya Perbaikan Ekonomi Masyarakat Di Desa Piloliyanga Kecamatan Tilamuta Kabupaten Boalemo. Universitas Negeri Gorontalo.

Badan Pusat Statistik Kota Serang, 2019. Kecamatan Kasemen Dalam Angka 2019. Serang : Badan Pusat Statistik.

Ife, Jim. 2008. Community Development : Alternatif Pengembangan Masyarakat di Era Globalisasi. Jogjakarta. Pustaka Pelajar

Resnawaty, Risna dkk. 2014. Pemberdayaan Ekonomi Lokal Melalui Pelatihan Perencanaan Bisnis Untuk Wirausaha Pemula. UNPAD. 